\title{
PREDICTION OF PHYSICAL VARIABLE TO SQUAT LONG JUMP ACHIEVEMENT (A MULTIVARIATE CORRELATIONAL STUDY ON TRAINED STUDENTS OF A STATE SENIOR HIGH SCHOOL IN PEKALONGAN REGENCY)
}

\author{
Abdurrachman ${ }^{1}$, Sugiyanto ${ }^{2}$, Muchsin Doewes $^{3}$ \\ ${ }^{1}$ Sebelas Maret University of Surakarta, Indonesia \\ mans.fisio@gmail.com
}

\begin{abstract}
First draft received: 14 Nov 2017 Accepted: 6 Jan $2017 \quad$ Final proof received: 22 Feb 2018
Abstract

Achievement of squat long jump needs to be supported with several components that are divided into anthropometric elements and physical abilities. This study aims to determine the relationship and the extent to which squat long jump achievement can predict limb length, body mass index, body flexibility, and running speed. The subjects of this research were trained students of state senior high schools in Pekalongan Regency, with a total sample of 60 students. The independent variables in this research included limb length, body mass index, body flexibility, and running speed, whereas the dependent variables consisted of long jump and squat style achievement. The data were obtained through the test and measurement of each variable. This study used multivariate correlational method. Data were analyzed with normality test, linearity test, simple and multiple regression analysis, and hypotheses were tested with $t$-test and $F$-test. The results showed that limb length, body mass index, and flexibility had a positive relationship, whereas body mass index and running speed had a negative relationship with the squat long jump achievement. The prediction value of limb length was 0.027 , body mass index 0.049 , body flexibility 0.026 , and running speed -0.234 . The conclusion of this study is that there was a significant relationship among the variables, and limb length, body mass index, body flexibility and running speed can be predicted based on squat long jump achievement.

Keywords: limb length, body mass index, body flexibility, running speed, squat long jump achievement

To cite this paper (in APA style):

Abdurrachman, Sugiyanto, \& Doewes, M. (2018). Prediction of physical variable to squat long jump achievement (A multivariate correlational study on trained students of a state senior high school in Pekalongan Regency). International Journal of Education, 10 (2), 101-106. doi: http://dx.doi.org/
\end{abstract}

\section{INTRODUCTION}

Sport is a conscious and systematic process that is carried out through various activities in order to gain ability and skills according to the individual's physical and mental conditions. Sports activities involve cognitive, affective, and psychomotor aspects. Athletics is the "mother" of most sports, where athletic movements such as walk, running, jump and throwing are subsumed under athletics (Bahagia, 1999). Athletics is a combination of several types of sports that can be grouped into running, throwing and jumping. Bahagia (1999) listed types of jumping in athletics, namely long jump, jumping up, high jump, and pole vault.

Long jump is "a jumping movement that begins with a horizontal movement and is transformed into vertical movement by doing repulsion on one of the strongest legs to get the distance as far as possible" (Wiarto, 2013, p. 32). According to Syarifuddin (1992), the long jump is a form of moving forward one foot in an effort to carry weight as long as possible in the air (flying in the air) and is done quickly by doing repulsive force on one foot to reach a distance as far as possible. The fundamental factor that a jumper must possess is the ability to master the technical skills and good physical condition. Adequate physical condition will support the appearance of long jump when making a leap. Thus, physical condition becomes important for jumpers because it is a foundation for learning techniques, tactics, strategies, and the psychology. in the opinion of Suharno (1993), the factors that determine maximal achievement include: (1) indigenous factors: good physical and mental health, body shape and body proportions, physical conditions and abilities, perfect mastery of techniques, mastery of strategies to problems, having the psychological aspect and good personality and having the maturity of soul; (2) Exogenous factors: Coach, coach assistant, trainer, venue, equipment, finance, organization, environment, government participation, methods, 
and training system. As for some components of the physical condition that greatly support the achievement of the long jump, they are power, strength, flexibility, speed, agility, balance, coordination, and reaction (Sajoto, 1998).

Several studies have been conducted related to jumping style of long jump performance with varying results, including Azizi (2014) who studied the contribution of limb muscle strength, weight, and body height to squat long jumpand found that leg muscle strength, weight, and height contributed to the ability of long jump squat style. Huda \& Subiono (2016) discovered that the factors of speed, weight and explosive power had an average contribution of $69.3 \%$ to long jump ability. A significant correlation between back flexibility and limb length and long jump ability was found by Ilham (2016). Davis et al. (2012) Results from this study suggest that jumping and sprinting are related to success in ultimate athletes. The authors suggested that future research in similar populations should include more performance tests, such as the repeated anaerobic sprint test protocol (RAST), and agility tests, such as the pro-agility test, as these might prove to be useful screening tools. From a practical standpoint, results from these tests also can provide an evaluation of the athletes, as well as the efficacy of strength and conditioning programs. Finally, Yaqin (2013) revealed that there was no effect related to the prefix distance on the long jump, but the speed at the long jump influenced the result of the long jump squat style.

Based on the description above, the study aims to determine whether there is a relationship and prediction on the factors of anthropometric and physical ability to the achievement of long jump squat style, as research on this area has not been found in the literature. The anthropometric factors referred to here are limb length and Body Mass Index (BMI), whereas the physical condition includes back flexibility and running speed.

\section{LITERATURE REVIEW}

Long jump is one of the branches in athletic sports. As a branch from athletic sports, movements performed in long jumps are combined with the athletic basic movements, namely running movements in the prefix to provide maximum repulsion and jump movement as it goes on to optimize the distance of the jump (Syarifuddin, 1992).

The long jump is a form of jumping movement that begins with a horizontal movement and is transformed into a vertical movement by performing repulsive force on one of the strongest legs to obtain the greatest distance (Wiarto, 2013). Ballesteros in Mardiana, Purwadi, and Satya (2009) suggested that long jumps are the result of horizontal speeds made during the prefix with the vertical power generated from the strength of the repelling leg. According to
Santoso et al. (2007), long jump movement consists of: prefix, refuse, jump, float and landed in a sandbox.

According to Mardiana, Purwadi, \& Satya (2009) the basic principle of long jump is to build the beginning of the fastest and do the strongest repulsion toward the front-up with one leg to reach the optimal height when flying so as to produce a long distance leap. This is similarly put forward by Sumardi (2000, p. 13) who stated, "Long jump is a movement of lifting the body from one point to another further or taller with a square run fast or slow by resting one leg and landing with the feet or other limbs with a good balance".

Marwanto (2007) explained that the length of the limb is the vertical distance between the feet to the groin as measured by standing upright. The limb as a member of the lower motion serves as a support for upper limb motion, as well as determinant of movement in walking, running, jumping or kicking. A person who has longer limb lengths will likely have a better jump because of the wider jump or step toward the front. So, the longer the limbs the further the jump or run in the long jump (llham, 2016).

The ideal body proportion is very important in achieving high achievement, as each sport demands an ideal body in accordance with the terms of the sport that is followed. In general, athletes especially for long jump athletes should have the ideal height or portion (Amirudin, 2016). Hamlin and Sugiyama (2013) stated that the body influences a person's ability to exercise. This is very much true for the long jumping athlete, because with a good body proportion the athlete will easily do repulsion and get longer drift time during the phase of drift. As Hidayatullah (2003) argued, athletic athletes with high achievements require a special biological profile with features of biometric ability and good psychological characteristics. The biometric aspects include weight, height of the body type. So the achievement of squat long jump is determined by ideal weight or lightweight to help create a longer drift in the air.

Meanwhile, back flexibility is thought to play a role in the determination of the long jump achievement whereby an athlete is concerned with the body during the floating phase, because the back flexibility makes it easier for an athlete to position his body while flying and also when it falls (Ilham, 2016). The back flexibility will provide the angle of movement in the long jump swing. In this case, it is explained that flexibility is the effectiveness in an athlete's adjustment to do all the body activities with stretching as far as possible, especially on the muscles and ligaments around the joints. The higher the back flexibility, the greater the angle of body movement in the swing, so that the power generated is also greater at the time before touching the sand when both legs are extended 
forward and the body bent (Jarver, 2005). Back flexibility is visible at the time of the fly where the body rapidly tends its forward so that both limbs can reach the farthest point in the jump result.

Finally, running speed or prefix speed is one component of basic physical conditions that may affect jumping achievement in long jump numbers. The running speed of a jumper can increase the power of the forward impulse and when doing repulsion or take off (Jarver, 2005). Speed here is defined as the ability to perform similar movements in a row in the shortest possible time or the ability to pursue a motion in the shortest possible time (Harsono, 1988). Running speed is defined simply as the step length or step frequency. To increase running speed is by increasing one or both of these parameters, keeping in mind the good running technique (Syarifuddin, 1992).

\section{METHODS}

This study used correlational method with survey, test, and measurement. Tests and measurements were performed to obtain a description of the relationship and predictions of limb length (X1), body mass index (X2), body flexibility (X3) and running speed (X4) on the squat long jump achievement (Y).

This study was conducted from May-June 2017. The population of this research included the trained students who of state senior high schools in Pekalongan Regency. Samples were taken using a simple random sampling technique, resulting in 60 students.

The measurement instruments used in this study were as follows: the limb length used midline measuring instrument; body mass index using body weight and height with strata meter and scales; body flexibility using the flexibility test with sit and reach test; running speed using a 40 meter run track and a stopwatch; and squat style long jump achievement using field squat style long jump test and a meter gauge.

The measurement data were analyzed with regression techniques. Before performing the test of analysis, a number of test requirements to determine the feasibility of data were carried out. The prerequisite test consisted of a test of normality and a linearity test. After the prerequisite test, the next analysis was hypothesis test, including the correlation coefficient analysis, multiple linear regression, $F$-test and $t$-test. The research data were processed using SPSS 19.0 application. This application can help calculate data to reduce errors in calculations.

\section{RESULTS}

Based on the measurements of the variables of limb length, body mass index, body flexibility, running speed, and squat style long jump achievement conducted, the following results were found: limb length minimum 70 and maximum 90, mean 78.6 with a standard deviation of 4.4501 ; body mass index (BMI), min. 17 and max. 29.4, mean 21.6 with a standard deviation of 2.8177 ; body flexibility min 23, max. 47, mean 34.4 with a standard deviation of 5.5945 ; running speed min. value of 4.2 , max. value of 6.6 , mean 5.3 with a standard deviation of 0.6533 ; and achievement of squat style long jump: minimum value 3.2 , max. value 5.2 , mean 4.4 with a standard deviation of 0.4330 .

The results of data normality test performed on each group using SPSS 19.0 application through Kolmogorov-Smirnov test are provided in Table 1.

Table 1 Normality Test

\begin{tabular}{lccc}
\hline & \multicolumn{3}{l}{ Kolmogorov-Smirnov ${ }^{\mathrm{a}}$} \\
\cline { 2 - 4 } & $\begin{array}{c}\text { Statist } \\
\text { ic }\end{array}$ & Df & Sig. \\
\hline Limb Leght & .104 & 60 & .174 \\
\hline Body Mass Index & .079 & 60 & $.20{ }_{*}$ \\
\hline Body Flexibility & .092 & 60 & $.200_{*}$ \\
\hline Running Speed & .111 & 60 & .051 \\
\hline $\begin{array}{l}\text { Long Jump } \\
\text { Achievement }\end{array}$ & .100 & 60 & $.200_{*}$ \\
\hline
\end{tabular}

From the normality test results in table 1, it was found that the data for all variables were normally distributed, as the values of significance for every variable were greater than 0.05 .

Table 2 Linearity of Regression Test

\begin{tabular}{|c|c|c|c|c|c|}
\hline Independent Variable & $\begin{array}{c}\text { Dependent } \\
\text { Variable }\end{array}$ & $\mathrm{F}$ & $\begin{array}{c}\text { Sig. } \\
\text { (linearity) }\end{array}$ & $\begin{array}{l}\text { Sig. (Deviation } \\
\text { from Linearity) }\end{array}$ & Linearity \\
\hline Limb Length $\left(X_{1}\right)$ & \multirow{4}{*}{$\begin{array}{c}\text { Squat Long } \\
\text { Jump } \\
\text { Achievement (Y) }\end{array}$} & 0,543 & 0,119 & 0,907 & Linier \\
\hline Body Mass Index $\left(\mathrm{X}_{2}\right)$ & & 2,230 & 0,005 & 0,157 & Linier \\
\hline Body Flexibility $\left(\mathrm{X}_{3}\right)$ & & 1,035 & 0,000 & 0,447 & Linier \\
\hline Running Speed $\left(\mathrm{X}_{4}\right)$ & & 1,520 & 0,000 & 0,130 & Linier \\
\hline
\end{tabular}

Table 3 Coefficient Correlations Analysis 


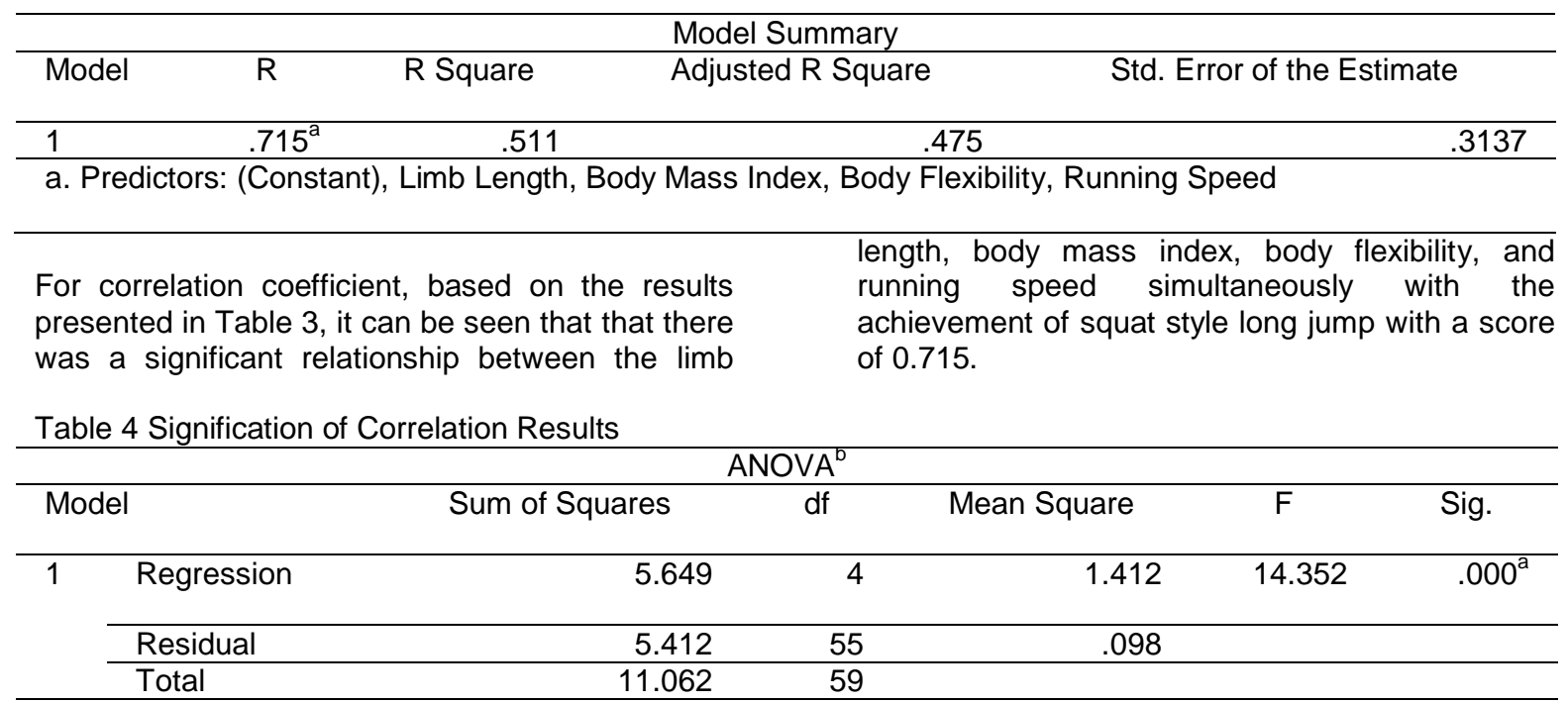

a. Predictors: (Constant), Limb Length, Body Mass Index, Body Flexibility, Running Speed

b. Dependent Variable: Squat long jump achievement

Hypothesis test for the variables of limb length, body mass index, flexibility, and running speed simultaneously using $F$-test with $5 \%$ significance level resulted in a significance value of $(0.000)$ $<0.05$ and $F_{\text {count }}=14.352>F_{\text {table }}=2.540$; then the hypothesis was accepted which means that there was a simultaneously significant relationship between the length of the limb, body mass index, body flexibility, and running speed with the squat style long jump achievement.

Table 5 Coefficient Multiregression Analysis Test

Coefficients $^{\mathrm{a}}$

\begin{tabular}{|c|c|c|c|c|c|}
\hline \multirow[b]{2}{*}{ Model } & \multicolumn{2}{|c|}{$\begin{array}{l}\text { Unstandardized } \\
\text { Coefficients }\end{array}$} & \multirow{2}{*}{$\begin{array}{c}\text { Standardized } \\
\text { Coefficients } \\
\text { Beta }\end{array}$} & \multirow[b]{2}{*}{$\mathrm{t}$} & \multirow[b]{2}{*}{ Sig. } \\
\hline & B & Std. Error & & & \\
\hline 1 (Constant) & 3.711 & .859 & & 4.319 & .000 \\
\hline Limb Length & .027 & .009 & .278 & 2.915 & .005 \\
\hline Body Mass Index & -.049 & .015 & -.318 & -3.223 & .002 \\
\hline Body Flexibility & .026 & .008 & .330 & 3.274 & .002 \\
\hline Running Speed & -.234 & .069 & -.352 & -3.382 & .001 \\
\hline
\end{tabular}

a. Dependent Variable: Squat long jump achievement

Similarly, as shown by Table 5 , the values of $t$ for all variables were greater than the $t_{\text {critical. }}$. This means there was individually a significant relationship between each of the variables (limb length, body mass index, body flexibility, and running speed) with the dependent variable of squat style long jump achievement.

The result of coefficient correlation analysis can be written in the following simple linear regression formula: $\hat{Y}=3.711+0.027 X 1-0.049 X 2+0.026$ $\mathrm{X} 3-0.234 \mathrm{X} 4$. The interpretation of the regression formula is as follow: Constanta (a) means that if the variables of limb length, body mass index, body flexibility, and running speed have the value of zero (0), then the value of the squat style long jump achievement variable is 3.711 .
Limb length coefficient value was 0.027 . This implies that the limb length variable had a positive relationship with the long jump achievement of the squat style which means that for each limb length increase, the jump in the squat style would rise by 0.027 meters with the assumption that the other independent variables of the regression model were fixed. Meanwhile, the coefficient value of body mass index was -0.049 . This implies that the body mass index variable had a negative relationship with the squat long jump achievement, which means any decrease in the body mass index by one unit would result in a rise by 0.049 meters in the jump, with the assumption that the other independent variables of the regression model were fixed. With a coefficient value of 0.026 , body flexibility had a positive correlation with the squat long jump achievement, 
which means that each increase of flexibility by one unit would increase the jump by 0.026 meters, with the assumption that the other independent variables from the regression model were fixed. Finally, the coefficient value of running speed was -0.234 . This implies that the variable of running speed had a negative relationship with the squat long jump achievement, which means any decrease in the running speed by one unit, then the squat long jump achievement would rise by 0.234 meters, with the assumption that the other independent variables of the regression model were fixed.

\section{Discussion}

In this study it was found that long jump athletes with different limb lengths would have different achievements in their jump results. Each increase of limb length by one unit would result in a rise by 0.027 meters in the jump. Although the data analysis shows the prediction of the length of the limb to the achievement of long jump is quite low, limb length is a strength advantage, because long legs do not rule out the effects on muscle strength. The longer the muscle, the stronger the move (Warsito, 2001). In terms of biomechanics, limb length has a longer range. Thus, long limbs have longer swings, which can help achieve maximum jump spacing. The advantage of limbs length is possible to increase the length of steps that can be taken (Syarifudin, 1992). This result is different from that of previous research (Azizi, 2014; Marwanto, 2007), where previous research has suggested that limb lengths contribute and even predict squat style jump performance. Meanwhile, in this study limb length had a fairly low analysis results, but basically still had a relationship and a prediction value.

The body mass index has a role in predicting the long jump with squat style. It means any decrease in body mass index of one unit will cause a rise by 0.049 meters in the jump. Body weight and height is a part in biometrics that can affect the achievement of sports. Adisasmita (1992, p. 65) sayd that "the attraction of the earth catches a point called "weight point". The weight is located at the waist, slightly below the navel. Hidayatullah (2003, pp. 12-13) added, "High achievement sports require a special biological profile with biometric abilities and good psychological characteristics. The biometric aspects include height, weight, height of sitting, length of upper and lower limbs, body type and others". So it can be concluded that anatomical factors, especially height and weight, are one of the most important supporting factors for a long jump athlete. This result is in accordance with that of previous study of Amirudin (2016) that the body mass index has a relationship, contribution and prediction of long jump results. Furthermore, as Sajoto (1988) pointed out, the determinants of sport achievement can be grouped into four aspects, one of which is the biological aspects which include: body posture and structure, consisting of height, body weight, and body shape. So, someone who has more stature will usually have long legs and will run fast and reach longer steps.

Previous research has also shown that body flexibility has an influence and can predict the long jump style with squat style results at the time before the landing, i.e. the foot is extended forward with the body bent forward (Ilham, 2016). Good landing is a continuation of the pattern on the long jump with squat style. At the moment before touching the sand, both limbs are straightened/stretched forward and the body bent forward (Jarver, 2015). The role of back spacing in the long jump is seen when the body whips forward as it flies. Good formation will provide a boost to mastery of techniques when performing long jump techniques, especially when flying in the air. In this study the variable of body flexibility also has a positive relationship with the achievement of long jump with squat style, which means any increase in body flexibility by one unit then the squat style long jump achievement will rise by 0.026 meters.

Meanwhile, running speed had a negative relationship with the achievement of long jump with squat style, which means any decrease in the running speed by one unit then the achievement of long jump with squat style will rise by 0.234 meters. Achievements that are optimal to achieve can be obtained by always paying attention to a fast technique, so that will produce a distance leap that is far. In this research, it is found that running speed is the most contributing factor to long jump with squat style, which is in correspondence with the result of previous research (Amirudin, 2016).

The results of this study show there was a relationship and prediction between the limb length, body mass index, body flexibility, and running speed simultaneously with the squat style long jump achievement. There was also a positive relationship between limb length and body flexibility; in other words, the greater the limb lengths and flexibility, the greater the results in the long jump with squat style achievement. The variables of body mass index and running speed also had a positive relationship, which means if the body mass index and running speed were smaller, the results of the long jump with squat style achievement would be greater. Thus, in this study if an athlete has a long limb, an ideal body in this case with a low body mass index, great body flexibility, and fast running ability, the athlete will get maximum jump results. So, it can be concluded that limb muscle strength, weight and height, influence and support the maximum result of long jump with squat style. Still, there are other factors that affect the results of long jump with squat style that are not included in this study. 


\section{CONCLUSIONS}

Based on the results of the research, this study concludes that the variables of limb length, body mass index, body flexibility, and running speed have a partial and simultaneous relationship and become predictors of squat style long jump achievement of the trained students at state senior high schools in Pekalongan Regency. The results of hypothesis testing can be summarized as follows: There was a significant correlation between the length of the limbs and long jump with squat style achievement with a prediction of 0.027 ; there was a significant correlation between body mass index and long jump with squat style achievement with a prediction of 0.049 ; there is a significant correlation between the flexibility of the body and the long jump with squat style achievement with a prediction of 0.026 ; and there was a significant relationship between running speed and long jump with squat style achievement with a prediction of -0.234 .

Based on the above conclusions, then there are some suggestions addressed for teachers or athletic trainers, especially long distance sport coaches in developing students or athletes in that they should pay attention to the four factors that become research variables. Training programs should improve the ability of long jump with squat style. In the selection of athletes for sports, especially long jump squat style, the factors in the study can be taken as part of the consideration. Finally, subsequent researchers are suggested to redevelop the factors that predict the achievement of long jump with squat style.

\section{REFERENCES}

Mardiana, A., Purwadi, \& Satya, W.I. (2009). Pendidikan jasmani dan olahraga. Jakarta: Universitas Terbuka.

Yusuf, A. (1992). Olahraga pilihan atletik. Jakarta: Depdikbuid.

Amirudin, P.S. (2016). Kontribusi aspek anthropometri dan kapasitas fisik dominan terhadap prestasi lompat jauh gaya Schenepper. Sportif: Jurnal Pembelajaran Olahraga, 2(1), 23-36. Kediri: Universitas Nusantara PGRI Kediri.

Azizi, M.M. (2014). Kontribusi kekuatan otot tungkai, berat badan dan tinggi badan terhadap kemampuan lompat jauh gaya jongkok. Jurnal Kesehatan Olahraga, 2(2), 180-188.

Bahagia, Y. (1999). Pembelajaran athletik. Direktorat Pendidikan Luar Biasa. Jakarta: Depdikbud Dirjen.

Hamlin, M.J., \& Sugiyama, Koji. (2013). Relationship between physical fitness and body mass index in 11 and 12 year old school children of
New Zealand (Lincoln University) and Japan (Shizouka University). Journal Studies in Subject Development, 1, 195-206.

Harsono. (1988). Coaching dan aspek-aspek psikologis dalam coaching. Bandung: CV. Tambak Kusuma

Hidayatullah, M. F. 2003. Teknik Pemanduan Bakat Olahraga. Surakarta: Program Studi Umum Keolahragaan Program Pasca Sarjana. Universitas Sebelas Maret.

Huda, K., \& Subiono, H.S. (2016). Sumbangan kecepatan, berat badan daya ledak terhadap lompat jauh. Journal of Sport Sciences and Fitness, 1(1), 27-32.

Ilham, S. (2016). Hubungan fleksibilitas togok dan panjang tungkai terhadap kemampuan lompat jauh gaya Schnepper. Sportif: Jurnal Pembelajaran Olahraga, 2(1), 47-43. Kediri: Universitas Nusantara PGRI Kediri.

Jarver, J. 2005. Belajar dan berlatih atletik. Bandung: Poiner Jaya.

Davis, K. Rossi, S., Langdon, J., \& McMillan, J. (2012). The Relationship between jumping and sprinting performance in collegiate ultimate athletes. Journal of Coaching Education, 5(2), 24-37.

Ministry of Education and Culture of the Republic of Indonesia. (2014). Pendidikan jasmani, olahraga, dan kesehatan - edisi revisi. Jakarta: MoEC.

Marwanto, H. (2007). Sumbangan daya ledak otot tungkai dan panjang tungkai dengan hasil lompat jauh gaya jongkok pada siswa putra kelas XI SMA Negeri 13 Kota Semarang tahun pelajaran 2006/2007 (Unpublished undergraduate thesis). UNNES, Semarang.

Sajoto, M. (1998). Peningkatan dan pembinaan kondisi fisik dalam olahraga. Semarang: Effhara Daharsa Prize.

Suharno, H.P. (1993). Metodologi pelatihan. Yogyakarta: IKIP Yogyakarta

Syarifudin, A. (1992). Atletik. Jakarta: Depdikbud

Santoso, T.H.B. et al. (2007). Pendidikan jasmani olah raga dan kesehatan. Jakarta: Yudhistira.

Warsito. 2001. Hubungan panjang tungkai dan kekuatan otot tungkai terhadap hasil lari 100 meter pada siswa putera sekolah dasar negeri kelas VI di Kecamatan Pekalongan Timur Kota Pekalongan tahun pelajaran 200/2001. UNNES, Semarang.

Wiarto, G. (2013). Atletik. Yogyakarta: Graha IImu.

Yaqin, A. (2013). Pengaruh awalan lari $10 \mathrm{~m}$ dan 20 $\mathrm{m}$ terhadap hasil belajar lompat jauh gaya jongkok. Jurnal Pendidikan Olahraga dan Kesehatan, 1(2), 400-405. 